\title{
FHDC1 Gene
}

National Cancer Institute

\section{Source}

National Cancer Institute. FHDC1 Gene. NCI Thesaurus. Code C114604.

This gene may play a role in cellular filament polymerization. 